\title{
RELATIONSHIP INTEREST IN LEARNING AND INTELLIGENCE INTELLECTUAL WITH LEARNING RESULTS ISLAMIC EDUCATION OF STUDENTS STATE ELEMENTARY SCHOOL IN BANDAR SETIA VILLAGE DISTRICT PERCUT SEI TUAN
}

\author{
Nuralam Siregar* \\ *Teacher In Deli Serdang Regency, North Sumatra
}

\begin{abstract}
This study aims to determine the magnitude of the relationship of interest in learning and intellectual intelligence to the learning outcomes of Islamic Education in elementary school students in Bandar Setia Village, Percut Sei Tuan District. The sample in this study amounted to 34 people taken from $10 \%$ of the total student population of 333 people. This study uses data collection tools in the form of questionnaires. The questionnaire is compiled based on variable indicators and then conducted a trial to the respondents who entered the sample in this study. The data analysis process was carried out in three stages: (1) describing the data of the research variables, (2) testing the analytical requirements, (3) testing the hypothesis to determine the relationship between the variables of the study using correlation analysis techniques. Conclusions based on data analysis and testing process are described as follows: (1) learning interest has a positive and significant relationship with learning outcomes. (2). intellectual intelligence has a positive and significant relationship with learning outcomes. and (3). learning interest and intellectual intelligence together have a positive and significant relationship. On the basis of the results of these studies it can be stated that the interest in learning and intellectual intelligence has a positive and significant effect on learning outcomes both individually and together.
\end{abstract}

\section{Keywords: Learning, Intelligence Intellectual, Learning Results}

\section{INTRODUCTION}

Learning outcomes are influenced by several factors, including family, social, school conditions, child psychology including; study habits, motivation, intellectual intelligence, interest in learning. Suryabrata (2011: 233) divides learning factors into three parts namely; child psychological, social and non-social factors. Child psychological factors include; motivation, interest, intelligence, study habits, learning styles. social and non-social factors include factors in schools, families, the surrounding environment, as well as facilities and infrastructure that support the implementation of the learning process. 
Furthermore Siregar and Nara (2010: 87) explain that there are two main factors that affect learning outcomes, namely: (1) internal factors include: physiological factors consisting of body conditions, certain physiological functions and psychological factors including talent, interest, intelligence and motivation, and (2) external factors are: social factors include the family environment, namely parents, home atmosphere, family economic ability, cultural background, teacher environment, namely teacher and student interaction, relationships between students, ways of presenting learning materials, and the environment community, namely the lifestyle of the environment, activities in the community and mass media and non-social factors including school facilities and infrastructure, namely curriculum, educational media, the state of the building, learning facilities, study time, home and nature.

One of the factors that influence learning is learning interest. The amount of interest in learning that students have will greatly help them to undergo the learning process. Interest is defined as liking and liking something or activities. Related to the learning process, interest becomes important, with the interest in learning students will have a sense of love and enjoy learning, so that it will foster a high curiosity in all subjects including Islamic Religious Education.

Another factor that influences learning outcomes is intellectual intelligence. Intellectual intelligence is often the main benchmark in determining judgment. In general, individuals who have a high level of intelligence will have high learning outcomes, and vice versa if the intellectual intelligence of individuals is low then the learning outcomes are also low. Students who have a high level of intelligence will be more receptive to information, more active in learning, easy to answer practice questions, conversely if students have low intelligence abilities, they will experience learning difficulties, are slow to receive information, have no interest in learning activities. Thus, the intelligence factor has a major influence on learning outcomes.

\section{THEORITICAL REVIEW}

Arifin (2009: 140) states learning is a process of changing behavior with experiences, can be interpreted as a process of bringing change in the way a person responds to the results of information with the surrounding environment. Shah (2017: 85) explains learning in the perspective of 
Islamic religion, the emphasis is more on the significance of cognitive functions (aqliah aspects) and sensory functions (senses) as important tools for learning, the importance of using the realm of human creativity and initiative in learning and achieving knowledge knowledge is widely discussed in the Qur'an with key words such as ya'qilun, yatafakkarun, yubshirun, yasma'un and others. Islam views mankind as creatures born in a state of empty, unscientific knowledge, but Allah gives the physical and spiritual potential to learn and develop science and technology for the benefit of humanity itself.

Mardianto (2013: 39) states learning is an endeavor, which means that actions are carried out seriously, systematically, by utilizing all potentials possessed, both physically and mentally. Djamarah (2016: 13) explains learning is a series of physical and mental activities to obtain a change in behavior as a result of an individual's experience in interactions with his environment involving cognitive, affective and psychomotor. Passer and Smith (2007: 192), put forward the notion of learning that is, "learning is a process by which experience produces a relativity enduring change in an organism's behavior or capabilities".

Suryabrata (2011: 232) states that learning brings change that is marked by the existence of new skills acquired with effort. According to Ramayulis (2015: 337) learning is a process of change in the behavior of individuals obtained from certain experiences. Khairani (2013: 5) outlines learning is a psychological process that takes place in the interaction between subjects and their environment and produces changes in knowledge, understanding, skills, attitudes and habits that are relatively constant / fixed either through experience, training or practice. Hamdani (2010: 21) states learning is a change in behavior or appearance, with a series of activities, for example by reading, observing, listening, imitating and so on.

Learning outcomes are influenced by learning factors that are classified into two types, namely internal factors and external factors. Internal factors are factors that exist in individuals who are learning. External factors are factors that exist outside the individual (Slameto, 2016: $54)$.

Nurmawati (2016: 53) divides learning outcomes by referring to Bloom's theory, which is achieved through three domain categories namely cognitive, affective and psychomotor. Assessment in education also refers to these three domains in all subjects in the education unit, both 
from elementary to university level. Achievement of learning outcomes in Islamic Religious Education subjects is not only seen from the final value, but refers to the assessment derived from the learning process.

Interest is one of the factors that influence learning. It is very important to know how much students interest in learning, because by knowing this the teacher can implement and develop strategies in teaching so as to foster student interest in following his lessons. Interest is a settled tendency to pay attention to and remember some activities. Someone who is interested in an activity will pay attention to that activity consistently with pleasure (Djamarah, 2016: 166).

Syah (2017: 152) explains that interest means high tendency and excitement or a great desire for something. Hilgred in Slameto (2016: 57) formulates an interest is prisitting tendency to pay attention to and enjoy some activity or content. Khairani (2013: 137) states interest is a psychological symptom that shows the subject's interest in the object being targeted because the object attracts attention and causes feelings of pleasure. Djaali (2013: 121) states that interest can be expressed through statements showing that students prefer one thing to another, it can also be manifested through participation in an activity.

Whitherington in Bukhari's translation (1982: 123) divides interest in two ways, namely: (1) primitive interest, which is an interest in network needs, such as food and freedom of activity, and (2) cultural interest, which is an interest socially derived from higher learning deeds.

According to Sardiman (1997: 80) interest in a person has the following characteristics: (1) persevering in facing tasks (able to work continuously for a long time, never stopping before completion), (2) resilient in facing difficulties (not fast despair), and does not require outside encouragement to achieve as well as possible (not quickly satisfied with the achievements he achieved), (3) shows interest in various problems or problems for adulthood (eg issues of religious development, politics, economics, eradication of corruption, opposition against every criminal action, immoral and so on), (4) prefers to work independently, (5) is easily bored on routine tasks (things that are mechanical, repetitive so it is less creative), (6) able defend his opinion (if you are sure of something), and (7) like to find and solve problems.

Hamalik (2002: 161) put forward the function of interest, as follows: (1) encourage the emergence of behavior or an action, (2) interest functions as a director, and (3) interest functions as a mobilizer. Another function of 
interest in learning is described by Khairani (2013: 146-147) as follows: (1) interest facilitates concentration. Attention that arises without coercion and is obtained naturally can make it easier for someone to concentrate on a lesson, (2) interest in preventing distractions from outside attention. Someone easily distracted attention and concentration when there are disturbances from outside, such as the person who is talking, the easy diversion of attention to other things due to small interest in learning, (3) interest in strengthening the inherent learning material in memory. The ability to remember learning materials will be accomplished if a student has a high interest in his studies. If someone's interest is high then he will easily remember the lesson material, and (4) interest in reducing the boredom of learning in oneself. Boredom usually arises more often from within oneself than comes from outside oneself. The elimination of boredom in learning from someone also can only be done by simply growing interest in learning and then increasing that interest as much as possible.

Interest serves as an activator and motivator towards the development of productive conditions to achieve learning goals. Effendi (1984: 61-62) explains that interest is closely related to motivation, because the nature of human beings is always moving to meet the needs of life, such as: meeting physiological needs (physical), fulfilling security or protection needs, meeting social life needs and meeting the needs of society satisfaction.

One other important factor in learning is intellectual intelligence. Intellectual intelligence affects student learning in terms of cognitive. Lahey (2007: 308) describes the meaning of intelligence, that is, intelligence refers to our ability to use cognitive processes to cope with the demands of life. Intellectual intelligence is the qualification of human intelligence which is dominated by the ability of rational thought and logic.

Approximately $80 \%$, intellectual intelligence is inherited from parents, while the rest is formed at a very early age ie 0-2 years in the first human life. Its relative nature is used as a predictor of individual success in the future and as its implication based on a number of studies to find intellectual intelligence test devices designed to enter the world of education as well as the world of work (Agustian, 2004: 62).

Dwijayanti (2009: 24) outlines intellectual intelligence as an ability consisting of three characteristics, including: (1). The ability to direct thoughts or actions, (2). The ability to change the course of action when 
the action has been taken, and (3). The ability to criticize yourself. Purwanto (2007: 58-59) states there are differences in intelligence between one person and another that is influenced by several factors. Factors influencing these intelligence include: (1) trait: trait is determined by the traits and traits that are carried from birth, (2) maturity: human organs grow and develop. Each organ is said to have matured if it has reached the ability to carry out its functions. Maturity is closely related to age, (3) formation: formation is any condition outside oneself that influences the development of intelligence, (4) specific interests and traits: interest directs an action towards a goal and is an impetus for that action, and (5) freedom: freedom means that humans can choose certain methods of solving problems.

Intelligence can be measured by intelligence tests. Many theories to calculate intelligence, but not all can be done at all age levels. The theory of intelligence tests in children which is often used is the theory of the intelligence tests of the Binet-Simon model. This intelligence test is a psychological test that was first created by Alfred Binet and Theodore Simon (Mardianto, 2016: 13). This test theory uses a formula to calculate children's intelligence by comparing Mental Age (M.A) or called intelligence age, with Chronological Age (C.A) or also called calendar age and multiplied by 100 (Suryabrata, 2011: 152).

\section{METHODS}

The research method used is quantitative correlational. The sample in this study amounted to 34 people drawn from $10 \%$ of the total student population of 333 people. This study uses a data collection tool in the form of a questionnaire. The questionnaire was arranged based on variable indicators then tested on respondents who did the sample in this study. The process of data analysis is carried out in three stages namely: (1) describing the research variable data, (2) testing the analysis requirements, (3) testing the hypothesis to determine the relationship between the research variables using correlation analysis techniques.

\section{RESEARCH RESULTS AND DISCUSSION}

The findings of this study indicate that there is a positive and significant relationship between learning interest with learning outcomes with a correlation rate of 0.417 . This shows the category of the relationship between learning interest and learning outcomes in the medium category. 
Learning interest also contributes effectively to learning outcomes with a figure of $14.90 \%$.

The relationship between the variables of interest in learning towards the learning outcomes of Islamic Religious Education grade IV students at SD Negeri in the village of Bandar Setia is,. In this case the variable of interest gives a positive contribution to learning outcomes. This means that if the learning interest factors present in students are in good condition, then this affects and contributes to the learning outcomes obtained by students who will also tend to be good. Conversely, if the factor of student interest in learning is bad, the learning outcomes will also tend to be of poor quality. Dalyono (1997: 56) believes that interest influences students' learning processes and outcomes, not much can be expected to produce good learning achievements from a child who is not interested in learning something.

The findings in this study are in line with several research results that use the same variable, namely learning interest, from the known results of learning interest contributes to the correlation in the low category, but it cannot be denied that interest in learning continues to contribute significantly to learning outcomes. Interest tends to be equated with liking or liking for something, as well as learning. Many factors can foster student interest, one of which is the teacher.

The teacher has an important role in increasing student interest in learning. Good and committed teachers always make optimal efforts to teach and support better student learning and achievement. Interest in learning can grow by itself if students feel interested in the teaching patterns of teachers who are creative and innovative. Students feel attracted and have a high curiosity about new things so that educating students becomes more independent and motivated. Antonius (2015: 119), learning that educates is learning that motivates students to learn independently and even raises the desire of students to discover new things from what they learn.

For the regression equation obtained $\hat{Y}=75.74+0.78 \mathrm{X}_{1}$. Based on these equations it can be explained that there is a positive correlation which if the score of student interest in learning increases, the learning outcomes obtained will also rise. As a prediction it can also be explained that if the factor of student interest in learning increases by one score, the score of learning outcomes will also increase by 0.78 . The constant value (a) of 75.74 follows that if the regression coefficient of learning interest 
(bX1) does not continue to be increased, student learning outcomes tend to decrease even reaching figures of 75.74. This may be due to factors of interest in learning contained in a student will determine the learning outcomes that will be achieved.

Based on the test of intellectual intelligence variable data shows high, medium, low and low categories as follows: the high category with a range of scores $\geq 102$ is $32.35 \%$, the medium category with a range of scores of 99 to 101 is $29.41 \%$, the category of less with the range of scores from 95 to 98 was $53.33 \%$ and while the low category with a range of scores $\leq 94$ was $14.71 \%$. Based on these data trends indicate that overall the majority of research respondents have a tendency in the high category of intellectual intelligence.

As with interest in learning, intellectual intelligence also shows a positive and significant relationship with learning outcomes with a magnitude of correlation 0.421 . This shows the category of the relationship between intellectual intelligence and learning outcomes in the moderate category. The effective contribution of the variable intellectual intelligence to learning outcomes is $25.10 \%$. This data makes an opportunity for Eastern Islamic Education Teachers to carry out learning by applying various methods or learning strategies that are varied because it is supported by the level of students' intellectual intelligence so that they can participate in learning optimally.

The research findings show that there is a significant relationship of intellectual intelligence on learning outcomes of Islamic Religious Education grade IV students of state elementary students in Bandar Setia Village, Percut Sei Tuan District. The contribution made by the variable of intellectual intelligence to the learning outcomes of Islamic Religious Education grade IV students of state elementary school students in Bandar Setia Village, Percut Sei Tuan District was $25.10 \%$. The relationship between intellectual intelligence on the learning outcomes of PAI State Elementary School students in Saentis is 0.421 .

This means that if the intellectual intelligence possessed by students is high, the learning outcomes of Islamic Religious Education grade IV students of SD Negeri students in Bandar Setia Village, Percut Sei Tuan District, will also tend to be high. Conversely, if the intellectual intelligence possessed by students is low, the learning outcomes of Islamic Religious Education grade IV students of state elementary students in Bandar Setia Village, Percut Sei Tuan District will also tend to be low. 
Intellectual intelligence is also called intelligence of thinking, can help humans to deal with and adapt to the environment, as well as solve problems logically by using abstract concepts so as to form more effective thinking structures. Furthermore, intellectual intelligence can potentially form attitudes or actions in the form of speed, ease and accuracy so that someone who has high quality intellectual intelligence will be able to solve problems easily, quickly and accurately.

The results of this study support logical arguments and correct ratios that the flow of information received by students must be accompanied by optimal intelligence capabilities to be able to digest the meaning of the information properly. It is often said that intelligence is an innate ability inherited by parents, but intellectual intelligence can basically be improved by educational and environmental factors.

The level of intellectual intelligence is one of the determining factors in the success or failure of students in school. Teachers 'understanding of the level of students' intellectual intelligence will help teachers in determining whether students are able to follow the learning process, and can be predicted success or failure of students after following the learning process.

In addition to being able to improve intellectual intelligence, it can also be developed so that students more quickly and appropriately solve life's problems and problems. Intellectual intelligence functions ranging from the level of remembering, understanding, applying, analyzing, synthesizing to evaluating into a thought process that breeds high creative reasoning from students. High intellectual intelligence is expected students are able to find solutions in life problems.

The regression equation in this study of the $X 2$ variables toward $Y$ was obtained $\hat{Y}=40.05+0.51 X 2$. Based on these equations it can be explained that there is a positive correlation which if the score of intellectual intelligence goes up, then student learning outcomes will also go up. As a prediction, it can also be explained that if the intellectual intelligence factor increases by one score, the score of learning outcomes of Islamic Religious Education students in the State Elementary School in Bandar Setia Village, Percut Sei Tuan District will rise by 0.51. The constant value (a) of 40.05 indicates that if the value of the intellectual intelligence regression coefficient (bX2) does not continue to be increased, the Islamic Religious Education learning outcomes of fourth grade 
students of SD Negeri in Bandar Setia Village, Percut Sei Tuan District, tend to decrease even reaching numbers up to 40.05 .

This may be because intellectual intelligence is an internal factor that exists in students who have a very important function in their lives. With this basis and reality, it will be possible for someone to develop their abilities so that they can grow even more optimally, including their learning outcomes.

Based on the data tendency test the learning outcomes variable shows the high, medium, low and low categories as follows: the high category with a range of scores adalah 94 is $26.47 \%$, the medium category with a range of scores from 90 to 93 is $41.187 \%$, the category of less with a range of scores 85 up to 89 at $20.59 \%$ and while the low category with a score range rentang 84 is $11.76 \%$. Based on the tendency of the data, it indicates that overall the majority of research respondents have the tendency of learning outcomes to be of the moderate category.

When examined further about the effective contribution of the two variables, namely the variable interest in learning and intellectual intelligence on learning outcomes is intellectual intelligence. This is because learning outcomes are determined by the presence of responsiveness or high intellectual abilities and of course also coupled with high learning interests carried out by students.

Interest in learning and intellectual intelligence together shows a positive and significant relationship with the magnitude of the correlation of 0.560 and the effective contribution given by the interest of learning and intellectual intelligence together towards learning outcomes is $33.30 \%$. This means that there are still more factors that can support learning outcomes not examined in this study.

The findings of the study show that there is a significant relationship between the variables of interest in learning and intellectual intelligence together on the learning outcomes of Islamic Religious Education for Grade IV students of SD Negeri in Bandar Setia Village, Percut Sei Tuan District. Contributions that were contributed by variables of interest in learning and intellectual intelligence together towards the learning outcomes of Islamic Religious Education students in grade IV Public Elementary Schools in Bandar Setia Village, Percut Sei Tuan District were $33.30 \%$. Hypothesis testing using multiple regression analysis shows the relationship of the two independent variables in this study (factors of interest in learning and intellectual intelligence) with the dependent 
variable (learning outcomes of Islamic Education and Learning for Grade IV students of state elementary schools in Bandar Setia Village, Percut Sei Tuan District) in this study is 0.560 .

Based on the calculation of the regression equation using multiple regression analysis (multiple regression) obtained the value of the two direction coefficients (bX1) of 0.67 , and (bX2) 0.72 with a constant value of 61.053. Thus the regression equation is $\hat{Y}=84.57+0.67 \mathrm{X} 1+0.72 \mathrm{X} 2$, this result means that the two independent variables in this study, namely interest in learning and intellectual intelligence are very important to be improved continuously as the main supporting factor in improving learning outcomes student.

Based on the results of the analysis of the two variables of learning interest and intellectual intelligence simultaneously affect the learning outcomes of Islamic Education. Interest is a sense of liking and interest in something both objects and activities and intellectual intelligence is the ability to obtain an ability to act or individual behavior. Both of these variables become important factors in improving learning outcomes. High learning interest coupled with high intellectual intelligence, learning outcomes will also increase.

So far, learning success is still marked by high scores. Realized or not both parents and teachers themselves, still identify the success of learning with high grades. High and low learning outcomes are always associated with the problem of teacher professionalism. Antonius (2015), a teacher can be said as a professional educator, if he has four competencies that have been holistically integrated and appear in the form of behavior when carrying out tasks and interacting with the environment in their daily lives. The four competencies are: (1) pedagogical competence, (2) personality competence, (3) social competence, (4) professional competency (field study competency).

The four competencies must be owned by a teacher, because the teacher is an important element in education. Success or failure of the learning process rests on the skills and expertise of teachers in carrying out the task. Students' interest will grow more if they feel interested and idolize the teacher so that what is conveyed is more easily absorbed. Students will have more curiosity and build independence to search for information, along with that the intellectual intelligence of students will increase and ultimately can improve student learning outcomes. 


\section{CONCLUSIONS}

The conclusions from the results of this study are: (1) there is a significant relationship between the variables of interest in learning with the learning outcomes of Islamic Education of State Elementary School students in Bandar Setia Village, Percut Sei Tuan District. The variable of interest in learning with the learning outcomes of Islamic Education of State Elementary School students in Bandar Setia Village, Percut Sei Tuan District, correlates by 0.417 . This means that if the factor of interest in learning is good, then the learning outcomes of Islamic Religious Education students at the State Elementary School in Bandar Setia Village, Percut Sei Tuan District tend to be good too. Conversely, if the factor of interest in learning is poor, then the learning outcomes achieved by students also tend to be low, (2) there is a significant relationship of intellectual intelligence with Islamic Religious Education learning outcomes of State Elementary School students in Bandar Setia Village, Percut Sei Tuan District. The variable of intellectual intelligence with the learning outcomes of Islamic Education of Elementary School students in Bandar Setia Village, Percut Sei Tuan District has a correlation of 0.417. This means that if the intellectual intelligence possessed by students is high, the learning outcomes obtained also tend to be high. Conversely, if the intellectual intelligence possessed by students is low, the learning outcomes obtained will also tend to be low, and (3) there is a significant contribution to the variable interest in learning and intellectual intelligence together with the learning outcomes of Islamic Religious Education of elementary school students in the village Bandar Setia District Percut Sei Tuan. The relationship between the two independent variables with the dependent variable is 0.560 . This means that the two independent variables in this study are related and at the same time make a positive contribution to the learning outcomes of Islamic Education in State Elementary School students in Bandar Setia Village, Percut Sei Tuan District.

\section{RECOMMENDATIONS}

Recommendations that can be given are: (1) the principal as the leader of the institution, in order to create an atmosphere and learning process that can enhance the various potentials and abilities possessed by students, by increasing the factors of interest and intellectual intelligence. Developing the potential and abilities possessed by students in the 
learning process becomes important and immediately implemented to make educational institutions truly able to play an optimal role. Psychological tests on students should be done at the beginning of the new school year so that teachers can know from an early age the level of intelligence possessed by students both intellectually, (2) teachers are also expected to develop competencies so that they can become professional teachers. The teacher is also expected to be able to create a conducive, dynamic and fun learning atmosphere and be able to empower all potentials that exist. Teachers can be more creative and active and innovate in every learning. Teachers are also expected to be able to apply learning models, using existing facilities and infrastructure to increase students' interest in learning and intellectual intelligence, (3) students are expected to increase their interest in learning and intellectual intelligence, so as to create intelligent people, it is also recommended to be able to utilizing available facilities and infrastructure, increasing their insights and knowledge in learning, and (4) to other researchers who want to conduct research related to improving student learning outcomes, it is advisable to review more broadly about the relationship of learning interest and intellectual intelligence with learning outcomes. Researchers who are interested in this field of study to conduct studies involving more predictor variables (independent variables) and respondents, so that other factors suspected of having a more meaningful contribution to student learning outcomes can be known in greater depth.

\section{REFERENCES}

Ari Ginanjar Agustian, Rahasia Sukses Membangun kecerdasan emosional dan Spiritual. Jakarta, 2004.

Arifin. H.M. Ilmu Pendidikan Islam Suatu Tinjauan Teoritis dan Praktis Berdasarkan Pendekatan Interdisipliner. Jakarta. Bumi Aksara. 2009.

Djamarah, Syaiful Bahri. Psikologi Belajar. Jakarta : Rineka Cipta, 2016.

Djaali. Psikologi Pendidikan. Jakarta : Bumi Aksara, 2013.

Dwijayanti, Ari Pangestu. Pengaruh Kecerdasan Emosional, Kecerdasan Intelektual, Kecerdasan Spiritual dan Kecerdasan Sosial Terhadap Pemahaman Akuntansi. Jakarta: Rosda Karya, 2009.

Efendi, Usman, Pengantar Psikologi, Angkasa, Bandung. 1984.

Goleman, Daniel. Working With Emotional Intelligence.Diterjemahkan kedalam Bahasa Indonesia. Jakarta: Gramedia Pustaka Utama. 2005. 
Hamalik, Oemar. Psikologi Belajar dan Mengajar. Cetakan kedua. Bandung: Sinar Baru Algsindo, 2002.

- Perencanaan Pengajaran Berdasarkan Pendekatan Sistem,

Jakarta : Bumi Aksara, 2002.

Hamdani. Strategi Belajar Mengajar. Bandung : Pustaka Setia, 2010.

Khairani, Makmun. Psikologi Belajar. Yogyakarta : Aswaja Pressindo, 2013.

Lahey, Benjamin B. Psychology. An introduction. Ninth Edition. New York: Mc. Graw Hill, 2007.

Mardianto. Pembelajaran Tematik. Cetakan ketiga. Medan: Perdana Publishing, 2016.

Nurmawati. Evaluasi Pendidikan Islam. Bandung : Cita Pustaka Media, 2016.

Passer, Michael W. dan Smith, Ronald E.. Psychology. The Sience of Mind And Behavior. Third edition. New York : Mc. Graw Hill, 2007.

Purwanto, Ngalim. Psikologi Pendidikan. Cetakan kesepuluh. Bandung: Remaja Rosdakarya, 2007.

Ramayulis. Ilmu Pendidikan Islam. Jakarta : Kalam Mulia, 2015.

Sardiman, A.M. Interaksi dan Motivasi Belajar Mengajar. Jakarta: Rajawali Press, 1997.

Slameto. Belajar dan Faktor-Faktor yang Mempengaruhi. Jakarta : Rineka Cipta, 2016.

Suryabrata, Sumadi. Psikologi Pendidikan. Jakarta : PT. Raja Grafindo

Perkasa, 2011.

Syah, Muhibbin. Psikologi Belajar. Jakarta: PT. Raja Grafindo Persada, 2017. 